\title{
Sustainable Communities and Multi Stakeholders Economics
}

\author{
Hiroshige Tanaka* \\ Professor Emeritus of Chuo University, Tokyo, Japan
}

Submission: August 31, 2021; Published: September 14, 2021

"Corresponding author: Hiroshige Tanaka, Professor Emeritus of Chuo University, Tokyo, Japan

\begin{abstract}
Sustainable global communities could be achieved by solving critical economic and social problems. Global market economies deteriorate problems such as climate change and disparity of wealth. To correct market and government failures the decentralized scheme that includes every stakeholder in the governance of communities is expected to improve the serious problems. By using bottom up systems, analyses on multi stakeholders become effective method in exploring sustainable global communities. Digital economies make possible to cooperate and communicate with many stakeholders. The exploration of digital industrial revolution fucuses on the relation among the multi stakeholders and the corporation. Although digital economies are dominated by top-down rules, the analyses on multi stakeholders exhibit a sustainable way for digital communities.
\end{abstract}

Keywords: Digital industrial revolution; Sustainability; Centralized and Decentralized systems

\section{Introduction}

In the beginning of the $21^{\text {st }}$ century, the revolution of digital technology improves performances of production by integrating complicated networks of global communities. However, many countries are confronted with social problems such as climate change, social security and disparity society as well as economic problems of surging budgetary deficits and aging populations. Digital economies have been developing in the circumstance brought by previous market and government failures. Although digital economies are expected to propel innovation of economic system, we must construct the social scheme of social and economic governance to cooperate with digital economies. To achieve sustainable global communities, we should explore the structural changes in social and economic mechanism brought by digital economies.

\section{Multi stakeholders and digital economies}

The platformer in digital economies is efficiently connected with multi stakeholders. The corporation can maximize net benefit with cooperation of multi stakeholders. The digital technology that facilitates to share and exchange information improves cooperation. As the development of digital technology enable to proceed a large scale of information, the communication mechanism is requested to be fair and transparent.

Arrow [1] suggests that CSR (Corporate Social Responsibility) is an important subject for economics. Tirole [2] develops the theory of one stakeholder by exploring shareholder value ${ }^{1}$. Tanaka [4] produces the theoretical model of multi stakeholders to investigate CSR. Tanaka [5-8] expand the theoretical model of CSR to explore the sustainable mechanism of global communities. In this theoretical model, the corporation is supposed to seek for not only the profit but also the non-profit. To make clear the feature of digital economies, Tanaka [9-10] classifies stakeholders into inside, outside and external stakeholders. Inside stakeholders that obtain firm connection with the corporation and common interests are illustrated by regular customers, business partners and employees.

Outside stakeholders such as irregular employees and consumers are defined to take occasional relation with the corporation and are increasing by rising digital transactions. External stakeholders have not transaction with the corporation and are exemplified by the residents who cannot participate digital networks ${ }^{2}$. Tanaka [13-14] demonstrate that digital

${ }^{1}$ Mansell [3] argues failures of theories based on a single stakeholder

${ }^{2}$ Choudrie, Tsatsou, Kruria [11] and Hindman [12] explain the issues brought by external stakeholders. 


\section{Annals of Social Sciences \& Management studies}

industrial revolution enlarges outside stakeholders caused by shrinking inside and external stakeholders. This demonstration implies that the digital industrial revolution proceeds in the two steps. The Figure 1 illustrates explicitly the procedures. The curve $0 \mathrm{~F}$ presents the marginal social cost of the corporation before the digital innovation. The initial optimal production is indicated by $x^{m}$. The theoretical investigation states that the innovation of ICT raises the marginal social cost valuated by stakeholders from the curve $0 \mathrm{~F}$ to the curve $0 \mathrm{E}$ and the optimal production $x^{m}$ moves into $x^{i}$. Tanaka [15] suggests the possibility that the innovation of technologies triggers the shift of stakeholders from inside and external stakeholders to outside stakeholders. It means that the rising the curve $0 \mathrm{E}$ to the curve $0 \mathrm{D}$ increases production $x^{i}$ to $x^{r}$. Figure 1 indicates that the digital industrial revolution remains the social welfare loss expressed by the area of triangle GHJ. However, by accompanying enhancement of efficiency of communication scheme, digital industrial revolution can decline the social welfare loss denoted by the area of the trapezoid JHIK. The reduced production in the industrial revolution follows.

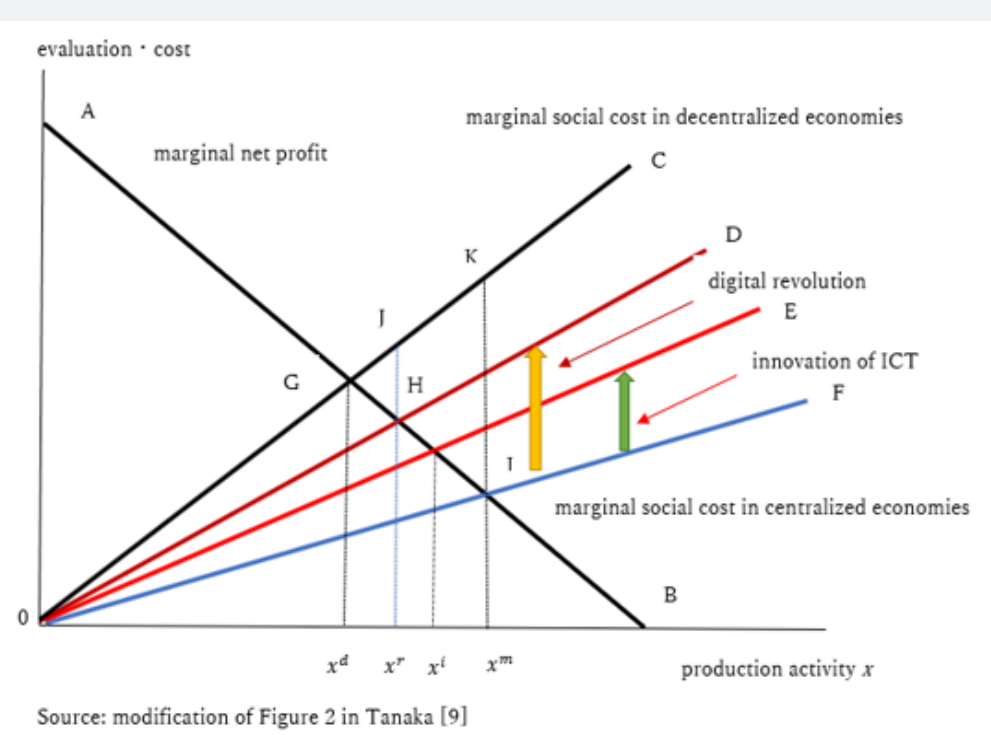

Figure 1: Sustainability and digital industrial revolution.

\section{Concluding Remarks}

This paper concludes that the digital industrial revolution brings rising outside stakeholders. Although the digital economies are expected to improve social welfare in some extend, some social welfare loss remains in the process of the industrial revolution. It is possible that the rising outside stakeholders could decline the remained social welfare loss. Tanaka [16] surveys that the change of stakeholders reforms the scheme of reginal governance in response of globalization and digitalization of economies ${ }^{3}$. Many municipalities in Tokyo area present the position of the outside stakeholder by supporting voluntary program of corporations and expecting not direct but tax contribution on the region ${ }^{4}$. The municipalities to transform into outside stakeholders aim to achieve sustainable communities.

\section{References}

1. Arrow KJ (1973) Social Responsibility and Economic Efficiency. Public Policy 21: 303-317.

2. Tirole J (2001) Corporate Governance. Econometrica 68(1): 1-35.

3. Mansell SF (2013) Capitalism, Corporations and the Social Contract: A Critique of Stakeholder Theory, Cambridge University Press, Cambridge, UK

4. Tanaka H (2004) Kigyo no Syakaiteki Sekinin no Keizai Riron (Japanese; Theoretical Analysis for Corporate Social Responsibility). Chikyuu Kankyu Report (Japanese; Global Environmental Policy in Japan), 9, pp.1-9.

5. Tanaka H (2016) The Sustainability Theorem in the ESG Mechanism. Long Finance and London Accord, pp,1-29.

6. Tanaka H (2017) Sustainability of Global Communities and Regional Risk Governance. Asia Pacific Journal of Regional Science, 1: 639-653.

${ }^{3}$ This report surveys the municipalities belonging to Tokyo Area (Tokyo, Saitama, Kanagawa and Chiba

Prefectures) in Japan to explore regional governance from August through November 2013.

${ }^{4}$ The sources are obtained Figures 13 and 15 in Tanaka [16]. 


\section{Annals of Social Sciences \& Management studies}

7. Tanaka H (2018) Mechanism of Sustainability and Structure of Stakeholders in Regions. Financial Forum 7(1): 1-12.

8. Tanaka H (2019) Rehabilitation of the Decentralization in the Centralizing Process of Global Communities. Journal of Global Issues and Solutions 19(3): 1-18.

9. Tanaka H (2019) Innovation on the Digital Economies and Sustainability of the Global Communities. Annals of social sciences \& management studies, Juniper 4(2): 1-10.

10. Tanaka H (2019) Sustainable Governance of Marine Stakeholders. Oceanography \& Fisheries Open Access Journal, Juniper 11(1): 1-4.

11. Choudrie J, Tsatsou P, Kruria S (2018) Social Inclusion and Usability of ICT-Enable Services. Routledge, Abingdon, UK.

12. Hindman M (2018) The Internet Trap: How the Digital Economy Builds
Monopolies and Undermines Democracy. Princeton University Press, Princeton, USA.

13. Tanaka H (2020) Digital Revolution and Structural Reform of Stakeholders. Journal of Global Issues and Solutions 20(2): 1-7.

14. Tanaka H (2020) Digital Economic and Social Systems to be Featured by Stakeholders. Annals of social sciences \& management studies, Juniper, 5(4): 86-94

15. Tanaka H, Tanaka C (2021) Green Bonds Issuance and Stakeholders Governance. Annals of Social Sciences and Management Studies 6(5): $1-11$.

16. Tanaka H (2014) The Cooperative and Competitive Urban Municipality Policies in the Tokyo Area to target Transforming Community Needs. Long Finance and London Accord, pp. 1-19.

\begin{tabular}{l} 
Your next submission with Juniper Publishers \\
will reach you the below assets \\
- Quality Editorial service \\
- Swift Peer Review \\
- Reprints availability \\
- E-prints Service \\
- Manuscript Podcast for convenient understanding \\
- Global attainment for your research \\
- Manuscript accessibility in different formats \\
( Pdf, E-pub, Full Text, Audio) \\
- Unceasing customer service \\
Track the below URL for one-step submission \\
https://juniperpublishers.com/online-submission.php \\
\hline
\end{tabular}

